\title{
Hubungan antara kecerdasan emosional dan agresivitas pada remaja madya di SMA Dwijendra Denpasar
}

\author{
I Putu Agus Swadnyana dan David Hizkia Tobing \\ Program Studi Sarjana Psikologi, Fakultas Kedokteran, Universitas Udayana \\ davidhizkia@yahoo.com
}

\begin{abstract}
Abstrak
Masa remaja merupakan masa transisi dari masa kanak-kanak menuju masa dewasa. Perubahan-perubahan yang terjadi pada remaja dapat menyebabkan munculnya agresivitas akibat ketidakmampuan individu bertahan terhadap pengaruh negatif dari lingkungan. Mengenali emosi diri, kemampuan mengelola emosi, memahami orang lain serta membina hubungan dengan baik terhadapat lingkungan atau yang disebut dengan kecerdasan emosional erat kaitannya dengan agresivitas. Penelitian ini bertujuan untuk mengetahui hubungan antara kecerdasan emosional dan agresivitas pada remaja madya di SMA Dwijendra Denpasar. Subjek dalam penelitian ini adalah 292 siswa-siswi SMA Dwijendra Denpasar yang berusia 15-18. Subjek terdiri dari 144 pria dan 148 perempuan dengan rata-rata usia 16 tahun sebanyak 158 siswa. Metode pengambilan data menggunakan skala kecerdasan emosional (17 aitem; $\alpha=0.746)$ dan skala agresivitas (16 aitem ; $\alpha=0.863$ ) yang direplikasi dari penelitian Amanda. Data diolah dengan analisis regresi linier sederhana. Hasil analisis statistik menunjukkan hubungan yang signifikan antara kecerdasan emosional dengan agresivitas, dengan arah negatif $(r=-0.227 ; p=0.000)$, sehingga, dapat dikatakan bahwa semakin tinggi kecerdasan emosional maka tingkat agresivitas semakin rendah. Koefisien determinasi diperoleh sebesar 0.051 yang berarti bahwa variabel kecerdasan emosional dapat menjelaskan 5,1\% varians yang terjadi pada variabel agresivitas. Meskipun varians yang dapat dijelaskan nilainya kecil namun hubungan antara agresivitas dan kecerdasan emosional dapat diyakini sebagai hubungan yang fungsional.
\end{abstract}

Kata kunci: Agresivitas, kecerdasan emosional, remaja madya

\begin{abstract}
Adolescence is transition from childhood into adulthood. The transition can induce an aggressiveness caused by the person could not survive from the negative effect of environment. Knowing about self-emotional, ability in controlling emotion, understanding others and keep a good relationship between environment or what recently called by emotional quotient are very closed with aggressiveness. The ability in controlling emotion is very close with emotional quotient itself. The highest intensity of emotional quotient can decrease aggressiveness level. This Study aimed at knowing the coherence between Emotional Quotient toward Aggressiveness of Middle Adolescence in Senior High School of Dwijendra Denpasar. Subject at this study were 292 students from Senior High School of Dwijendra Denpasar in the age of 15 - 18 years old. The students were consisting of 144 male students and 148 female students. Instead, 158 students were in the age of 16 years old. The methods that used in this study were emotional quotient scale (17 aitem; $\alpha=0.746)$ and aggressiveness scale (16 aitem; $\alpha=0.863$ ) which is replicated from Amanda's research. Data was produced by using simple analysis of regresi linier. Statistic analysis of this study showed that emotional quotient and aggressiveness had significance coherence, trough negative direction $(r=-0.227 ; \mathrm{p}=0.000)$. So That, it can be decided if the level of emotional quotient was higher, aggressiveness was in lower level. Co-efficient of determination obtained at 0.051 means that variable of emotional quotient can explain 5,1\% variants that happened on aggressiveness variable. Even the variant that can be described having a small value, but the relation between aggressiveness and emotional quotient can be trusted as functional relationship.
\end{abstract}

Keywords: Aggressiveness, $\quad$ emotional $\quad$ quotient, $\quad$ middle-adolescence. 


\section{LATAR BELAKANG}

Menurut Feldman dan Elliot (dalam Khoirunnisa, et al., 2014) pada saat remaja berhubungan dengan lingkungannya, remaja banyak dihadapkan pada hal-hal yang penuh risiko dan godaan. Hal tersebut lebih banyak terjadi dan lebih beragam pada remaja saat ini dibandingkan dengan remaja sebelumnya. Terdapat sebagian remaja yang dapat bertahan dengan lingkungan yang penuh bahaya dan godaan. Walaupun demikian, terdapat remaja yang tidak dapat bertahan dari godaan-godaan tersebut sehingga mereka putus sekolah, hamil di luar nikah, tawuran, kebut-kebutan, perkelahian dan terlibat dalam penggunaan obat-obatan terlarang (Santrock, 2003). Keadaan seperti ini sering dianggap oleh orang dewasa sebagai kenakalan remaja.

Perilaku kenakalan remaja atau delinquent menurut Santrock (2003) merujuk pada berbagai perilaku, mulai dari perilaku yang tidak dapat diterima secara sosial (seperti berbuat onar disekolah), status pelanggaran (melarikan diri dari rumah) dan hingga tindakan kriminal (seperti pencurian). Saat ini, banyak kasus-kasus pelanggaran hukum yang melibatkan remaja. Salah satu kasus yang terkait dengan kenakalan remaja yang mengarah pada perilaku kriminal adalah kasus perkelahian sekelompok pelajar di Denpasar yang berujung pada kematian salah seorang remaja. Kasus ini terjadi akibat dendam yang dimiliki oleh pelaku kepada korban. Menurut Kapolsek Denpasar Selatan Kompol Nanang Prihasmoko, pelaku berinisial JS dengan usia 15 tahun dan korban AS dengan usia 16 tahun sebelumnya sudah berdamai, namun pada saat itu pelaku meminta korban untuk bertemu disebuah tempat di daerah Panjer tepatnya di jalan Waturenggong. Sesampainya korban di lokasi, pelaku langsung menyerang korban menggunakan pisau dan sempat terjadi perkelahian antara korban dan pelaku, namun akibat penusukan tersebut korban tidak dapat tertolong dan meninggal di rumah sakit Sanglah (Sukiswanti, 2015).

Selain itu, kasus lain yaitu sekelompok remaja yang berusia belasan tahun melakukan pencurian sepeda motor di jalan Sastra, Sidekarya. Pencurian ini dilakukan oleh dua orang pelaku yang berusia masing-masing 17 dan 18 tahun. Setelah berhasil melakukan pencurian sepeda motor, pelaku meminta rekannya yang lain untuk menjual hasil curian tersebut melalui situs toko online. Dari keterangan pihak kepolisian, tersangka pencurian sepeda motor sebelumnya juga pernah ditangkap oleh petugas Reskrim Polsek Denpasar Selatan karena melakukan pencurian sepeda motor di jalan Sidekarya Denpasar (Putra, 2016).

Terdapat juga kasus lain kenakalan remaja yang mengarah ke kriminalitas. Seperti yang terjadi pada tanggal 9 juli 2017 , sekelompok remaja berusia 16 sampai 19 tahun yang tergabung dalam sebuah geng motor melakukan pengeroyokan dan penusukan terhadap anggota TNI saat melintas di jalan bypass Ngurah Rai, Jimbaran Kuta Selatan, Badung. Kasus bermula ketika sekelompok geng motor mengendarai motor secara beriringan. Para pelaku berada di depan, sementara korban berada dibelakang. Sesaat sebelum tiba di lokasi kejadian, topi dari salah satu tersangka terjatuh dan tidak sengaja terlindas oleh motor korban. Tidak terima dengan hal tersebut, tersangka menghadang korban dan menganiaya secara bersamaan. Salah satu tersangka yang juga seorang anak anggota DPRD Bali melakukan penusukan terhadap korban yang mengakibatkan korban meninggal dunia (Purnomo, 2017).

Selain kasus pencurian dan pembunuhan yang terjadi pada contoh kasus di atas, perilaku kenakalan remaja yang merujuk pada perilaku agresif pernah meresahkan masyarakat di Bali. Tindakan kekerasan yang dilakukan oleh sekelompok remaja putri berusia 15 sampai 17 tahun yang tergabung dalam anggota geng motor di wilayah Denpasar diketahui telah melakukan tindak penganiayaan terhadap salah satu teman remaja putri yang juga merupakan kelompok anggota geng motor. Perkelahian yang terjadi bahkan sempat direkam oleh salah satu anggota yang ikut dalam penganiayaan tersebut. Penganiayaan yang dilakukan terhadap korban juga merupakan temannya sendiri terjadi di awal tahun 2012 dengan cara memukuli, menonjok, menampar, menjambak rambut korban serta menggunting baju dan celana korban hingga nyaris telanjang. Pemicu dari penganiayaan yang dilakukan adalah karena kekesalan yang dirasakan oleh salah satu anggota geng yang merasa tersinggung karena baju geng yang menunjukkan identitas kelompok tidak dipakai oleh korban melainkan diinjak-injak (Rohmat, 2012).

Kasus lain juga terdapat sekelompok remaja yang masih bersekolah di SMA Dwijendra Denpasar yang terlibat dalam kasus geng motor. Sekelompok siswa SMA Dwijendra yang tergabung dalam sebuah geng motor melakukan pengeroyokan dan perusakan mobil milik salah satu mahasiswa Kedokteran Universitas Warmadewa. Kelompok geng motor tersebut sempat melakukan ancaman kepada korban dengan menggunakan pedang yang dibawanya. Karena merasa terancam, korban melarikan diri, namun kaca mobil korban pada bagian belakang dipecahkan oleh kelompok geng motor tersebut (Surya, 2016).

Dari beberapa contoh kasus di atas, dapat dilihat bahwa perilaku agresif yang mengarah pada tindak kriminalitas didominasi oleh remaja dengan usia 15 sampai 18 tahun atau termasuk dalam katagori remaja madya. Data Pusat Pelayanan Terpadu Pemberdayaan Perempuan dan Anak (P2TP2A) kota Denpasar, pada tahun 2012 tercatat ada 12 anak yang terlibat kasus hukum, tahun 2013 jumlahnya meningkat menjadi 20 anak, pada tahun 2014 sebanyak 24 anak, tahun 2015 sebanyak 30 anak dan pada tahun 2016 hingga bulan Agustus sudah tercatat 27 anak di Denpasar yang berhadapan dengan hukum (Satria, 2016). Hal ini menunjukkan adanya peningkatan kasus-kasus pelanggaran hukum dari tahun ke tahun yang melibatkan remaja. Sebuah penelitian yang dilakukan oleh Santoso (2000) di Provinsi Bali dengan melibatkan remaja berusia 13 tahun hingga 19 tahun menunjukkan kenakalan remaja yang mengarah pada tindak kriminalitas, seperti pemerasan dan pencurian di kota Denpasar mencapai angka sekitar 7,2\% dan dikabupaten Gianyar sebesar 5,8\%. Pencurian yang dilakukan oleh remaja di kota Denpasar sebesar 8,9\% dan di Kabupaten Gianyar sebesar 17,7\%. Sementara itu, data dari Polda Bali menyebutkan pada tahun 2009 terdapat kasus kekerasan remaja dan $90,3 \%$ pelakunya berusia 13 - 18 tahun. Remaja sebagai pelaku kekerasan di Provinsi Bali terus mengalami peningkatan sebesar 3\% setiap tahun (Polda Bali, 2012). 
Sepanjang tahun 2017 hingga bulan Desember, Komisi Pengawas dan Perlindungan Anak Daerah (KPPAD) Bali mencatat 253 kasus hukum yang melibatkan anak sebagai korban maupun pelaku tindak pidana kejahatan. Berdasarkan jumlah tersebut, sebanyak 137 atau 54\% anak menjadi pelaku kejahatan yang didominasi oleh kasus pencurian sebanyak 68 anak dan keterlibatan dalam geng motor sebanyak 32 anak. Data yang ada dilapangan didasari oleh kasus-kasus yang memang melibatkan remaja sebagai pelakunya. Hal tersebut menunjukkan bahwa agresivitas remaja di Bali dalam kategori yang mengkhawatirkan.

Munculnya agresivitas pada remaja dipengaruhi oleh banyak faktor seperti faktor keluarga, sekolah dan lingkungan sekitar (Kurniawati, 2010). Sekolah merupakan salah satu faktor yang mengakibatkan munculnya agresivitas khususnya pada teman sebaya karena remaja lebih sering meluangkan waktu di sekolah. Remaja banyak menghabiskan waktu di sekolah dengan teman sebaya sambil mengikuti berbagai pelajaran, kegiatan maupun klub-klub yang ada di sekolah. Dilihat pada perkembangan emosi pada remaja menunjukkan sifat yang sensitif dan reaktif yang sangat kuat terhadap berbagai peristiwa ataupun situasi sosial, emosi yang bersifat negatif dan temperamental.

Repliein (dalam Monks, 2009) menyebutkan bahwa masa remaja merupakan tahapan krisis yang ditunjukkan dengan adanya kepekaan dan labilitas tinggi, penuh gejolak dan ketidakstabilan emosi, sehingga remaja rentan bereaksi apabila emosinya tersulut. Selain masa perkembangan, terdapat faktor lain yang menjadi penyebab dari pergolakan emosi yang dialami oleh remaja, yaitu lingkungan sosial yaitu lingkungan keluarga, sekolah, dan masyarakat (Dewi, 2012). Remaja yang melakukan tindak agresivitas dikarenakan remaja yang tidak mampu mengelola emosi diri dengan baik, sehingga ketika emosi memuncak dan tidak mampu dibendung lagi, emosi tersebut akan meluap-luap dan remaja akan melakukan tindakan yang tidak akan disadari seperti tindak agresivitas (Kurnia, 2012). Kemampuan mengelola emosi dengan baik sangat erat kaitannya dengan kecerdasan emosional seseorang.

Kecerdasan emosional adalah kemampuan untuk memotivasi diri sendiri, mampu bertahan pada saat mengalami frustasi dan menjaga keselarasan emosi dengan cara pengendalian diri, mengontrol dorongan (impulse), empati, dan keterampilan sosial. Kecerdasan emosional disetiap individu berbeda-beda, individu yang memiliki kecerdasan yang tinggi cenderung mampu untuk mengelola emosi dengan baik, sedangkan individu yang memiliki kecerdasan emosional yang rendah cenderung mengakibatkan agresivitas dan kemungkinan untuk menjadi depresi (Goleman, 1995). Seorang remaja yang memiliki sikap dan perilaku yang positif adalah seorang remaja yang memiliki kemampuan untuk mengendalikan diri dengan baik, mampu memahami perasaan diri sendiri dan orang lain, dan mampu membina hubungan yang baik dengan orang lain, dengan demikian remaja tersebut dapat dikatakan sebagai remaja yang memiliki kecerdasan emosional yang tinggi (Indrayana \& Hendrati, 2013). Berdasarkan paparan di atas, peneliti berasumsi bahwa terdapat hubungan pada kecerdasan emosional dan agresivitas. Oleh karena itu, peneliti tertarik untuk meneliti hubungan antara kecerdasan emosional dan agresivitas pada remaja madya di SMA Dwijendra Denpasar.

\section{METODE PENELITIAN}

\section{Variabel dan Definisi Operasional}

Variabel bebas dalam penelitian ini adalah kecerdasan emosional, serta variabel tergantung dalam penelitian ini adalah agresivitas. Agresivitas merupakan kecenderungan individu untuk menyakiti atau melukai orang lain baik secara fisik, verbal maupun psikis yang berasal dari emosi marah dalam diri individu. Taraf agresivitas diukur dengan skala agresivitas, semakin tinggi skor total yang diperoleh maka semakin tinggi taraf agresivitas. Kecerdasan emosional adalah kemampuan untuk memotivasi diri sendiri dan bertahan ketika individu mengalami suatu keadaan yang membuat frustasi, mengendalikan dorongan hati serta tidak melebih-lebihkan kesenangan yang dirasakan, mengatur suasana hati dan juga menjaga agar beban stres yang ada tidak melumpuhkan kemampuan berpikir, berempati. Taraf kecerdasan emosional diukur dengan skala kecerdasan emosional, semakin tinggi skor total yang diperoleh maka semakin tinggi taraf kecerdasan emosional.

\section{Responden}

Responden dalam penelitian ini adalah siswa kelas X dan XI SMA Dwijendra Denpasar. Karakteristik subjek penelitian yang digunakan adalah siswa yang berusia 15 - 18 tahun yang bersekolah di SMA Dwijendra Denpasar, berjenis kelamin laki-laki dan perempuan.

Subjek dalam penelitian ini adalah remaja madya dengan usia 15 sampai 18 tahun yang sedang menempuh pendidikan di SMA Dwijendra Denpasar yang berjumlah 292 siswa. Sebanyak 144 atau 49,3\% subjek berjenis kelamin laki-laki dan sebanyak 148 atau 50,7\% subjek berjenis kelamin perempuan. Mayoritas subjek dalam penelitian ini berusia 16 tahun sebanyak 158 atau 54,1\% yang terdiri dari 155 atau 53\% siswa kelas X dan 137 atau $47 \%$ siswa kelas XI.

Teknik sampling yang digunakan adalah teknik proportionate stratified random sampling yaitu pengambilan anggota sampel dari populasi dilakukan secara merata sesuai dengan tingkatan atau strata yang ada di (Sugiyono, 2014). Perhitungan jumlah sampel didasarkan pada tabel pedoman ukuran sampel dari Isaac dan Michael (dalam Sugiyono, 2013) dengan taraf kesalahan sampling 5\% adalah minimal 289.

\section{Tempat Penelitian}

Proses pengambilan sampel penelitian ini dilakukan di SMA Dwijendra Denpasar pada bulan februari 2018. Adapun proses pengambilan data pada penelitian ini melalui beberapa tahapan seperti mengajukan surat permohonan izin penelitian dari Program Studi Psikologi Fakultas Kedokteran Universitas Udayana dan KESBANGPOL kepada SMA Dwijendra Denpasar, menyampaikan maksud dan tujuan penelitian kepada kepala sekolah SMA Dwijendra Denpasar dan menentukan tanggal pelaksanaan pengambilan data penelitian. 


\section{Alat Ukur}

Alat ukur yang digunakan dalam penelitian ini adalah skala kecerdasan emosional dan skala agresivitas yang direplikasi dari Amanda (2015). Skala agresivitas yang digunakan dalam penelitian ini terdiri dari empat aspek agresivitas berdasarkan teori Buss dan Parry (dalam Bryant \& Smith 2001). Skala kecerdasan emosional yang digunakan dalam penelitian ini terdiri dari lima aspek kecerdasan emosional berdasarkan teori Goleman (2001). Skala agresivitas terdiri dari 16 aitem, sedangkan skala kecerdasan emosional terdiri dari 17 aitem. Model skala yang digunakan pada kuesioner ini adalah skala likert dan aitem-aitem pada kuesioner terdiri dari aitem favorable serta aitem unfavorable. Pada pernyataan aitem favorable, setiap jawaban Sangat Tidak Setuju (STS) akan diberikan nilai 1, Tidak Setuju (TS) akan diberi nilai 2, Setuju (S) akan diberi nilai 3, dan Sangat Setuju (SS) akan diberi nilai 4. Sedangkan dalam pernyataan aitem unfavorable, setiap jawaban Sangat Tidak Setuju (STS) akan diberikan nilai 4, Tidak Setuju (TS) akan diberi nilai 3, Setuju (S) akan diberi nilai 2, dan Sangat Setuju (SS) akan diberi nilai 1.

Hasil pengujian validitas skala kecerdasan emosional menunjukkan nilai koefisien korelasi aitem-total yang berkisar dari $0.252-0.541$. Hasil uji reliabilitas dengan menggunakan Croncbach Alpha adalah 0.746. Berdasarkan hasil pengujian maka skala kecerdasan emosional dapat digunakan untuk mengukur kecerdasan emosional pada subjek penelitian. Hasil pengujian validitas skala agresivitas menunjukkan nilai koefisien korelasi aitem-total yang berkisar dari $0.308-0.708$. Hasil uji reliabilitas dengan menggunakan Croncbach Alpha adalah 0.863. Berdasarkan hasil pengujian maka skala agresivitas dapat digunakan untuk mengukur agresivitas pada subjek penelitian

\section{Metode Pengumpulan Data}

Pada penelitian ini, teknik yang digunakan penelitian untuk mengumpulkan informasi dari subjek adalah dengan menggunakan skala atau kuesioner. Skala yang digunakan pada penelitian ini adalah skala kecerdasan emosional dan skala agresivitas. Peneliti melakukan random terhadap kelas X dan XI untuk dijadikan sampel penelitian, setelah mendapatkan kelas yang akan digunakan sebagai sampel, peneliti menyebarkan kuesioner yang kemudian diisi oleh responden.

\section{Teknik Analisis Data}

Teknik analisis data yang digunakan untuk dapat menguji hipotesis dalam penelitian ini adalah analisis regresi sederhana (simple regression analysis). Regresi sederhana digunakan untuk memprediksi nilai suatu variabel dependen berdasarkan nilai variabel independen (Ghozali, 2012). Selain itu, regresi sederhana digunakan untuk mengetahui arah hubungan antara variabel bebas dengan variabel tergantung. Sebelum melakukan analisis data dengan regresi sederhana, peneliti melakukan uji normalitas dan uji linearitas. Uji normalitas dalam penelitian ini dilakukan dengan menggunakan uji Kolmogorov - Smirnov, dan uji linearitas yang digunakan dalam penelitian ini adalah uji compare mean.

\section{HASIL PENELITIAN}

\section{Deskripsi dan Kategorisasi Data Penelitian}

Hasil deskripsi statistik pada tabel 1 (terlampir) menunjukkan bahwa Dari hasil deskripsi data penelitian pada tabel 1, dapat dijelaskan makna dari hasil tersebut sebagai berikut:

\section{Kecerdasan Emosional}

Berdasarkan tabel diatas, dapat dilihat bahwa terdapat perbedaan mean teoretis dan mean empiris pada skala kecerdasan emosional. Mean empiris terlihat lebih tinggi daripada mean teoretis yaitu sebesar 5.43. Hal ini menunjukkan bahwa rata-rata subjek dalam penelitian ini memiliki kecerdasan yang tinggi. Skor subjek memiliki rentang dari 32 sampai dengan 59 dan terlihat dari distribusi frekuensi terdapat sebanyak 90,41\% skor subjek yang berada diatas mean teoretis. Hasil dari kategorisasi variabel kecerdasan emosional menunjukkan bahwa remaja di SMA Dwijendra Denpasar memiliki tingkat kecerdasan emosional yang tinggi yaitu sebanyak 180 siswa atau $61,6 \%$.

Agresivitas

Pada skala agresivitas terdapat perbedaan mean teoretis dan mean empiris. Mean teoretis lebih besar daripada mean empiris yaitu sebesar 0.36 . Hal ini menunjukkan bahwa ratarata subjek dalam penelitian ini memiliki tingkat agresivitas kecil. Skor subjek memiliki rentang dari 22 sampai dengan 60 dan dilihat dari distribusi frekuensi terdapat 57,9\% skor subjek yang berada diatas mean teoretis. Hasil dari kategorisasi variabel agresivitas menunjukkan bahwa remaja di SMA Dwijendra Denpasar memiliki tingkat agresivitas yang sedang yaitu sebanyak 134 siswa atau 45,9\%.

\section{Uji Asumsi}

Berdasarkan tabel 4 (terlampir), Sebaran data variabel kecerdasan emosional menghasilkan nilai KolmogorovSmirnov sebesar 1.251 dan memiliki nilai signifikansi sebesar 0.087 ( $>0.05)$ yang memiliki arti bahwa terdapat distribusi yang normal pada variabel kecerdasan emosional. Sebaran data variabel agresivitas menghasilkan nilai kolmogorofsmirnov sebesar 0.835 dan memiliki nilai signifikasi sebesar 0.488 ( $p>0.05)$ yang memiliki arti bahwa terdapat distribusi yang normal pada variabel agresivitas. Dari hasil uji linearitas pada tabel 5 menunjukkan bahwa adanya hubungan yang linear antara agresivitas dan kecerdasan emosional yang memiliki nilai signifikansi 0.000 atau lebih kecil dari 0.05 . Hal ini berarti bahwa terdapat hubungan yang linear antara agresivitas dan kecerdasan emosional.

\section{Uji Hipotesis}

Hasil analisis korelasi Pearson Product Moment pada regresi sederhana menunjukkan koefisien korelasi sebesar -0.227 dan signifikansi sebesar $0.000 \quad(\mathrm{p}<0.05)$. Hal ini menunjukkan bahwa kecerdasan emosional memiliki korelasi yang signifikan dengan arah negatif terhadap agresivitas.

Tabel 7 (terlampir) menunjukkan koefisien korelasi (R) sebesar 0.227 , sedangkan koefisien determinasi sebesar 0.051 . Pada penelitian ini koefisien $\mathrm{R}$ tergolong rendah, korelasi diantara kedua variabel bebas dan variabel terikat yaitu kecerdasan emosional terhadap agresivitas tergolong baik dan kuat apabila koefisien angka berada diatas 0.5. Sumbangan 
efektif dari kecerdasan emosional terdapat agresivitas adalah $5,1 \%$ dan sisanya sebesar $94,9 \%$ dipengaruhi oleh variabel lain yang tidak dimasukkan dan tidak dibahas pada penelitian ini.

Pada tabel 8 (terlampir) dapat dilihat nilai perbedaan varians antara kecerdasan emosional dan agresivitas atau $F$ hitung sebesar 15.700 dengan taraf signifikansi 0.000. Dasar untuk melakukan pengambilan keputusan adalah apabila $\mathrm{p}<0.05$ maka model regresi dapat digunakan untuk memprediksi variabel tergantung. Berdasarkan hasil uji $\mathrm{F}$, diperoleh nilai probabilitas $0.000<0.05$ sehingga model regresi diatas dapat digunakan untuk memprediksi nilai agresivitas.

Berdasarkan hasil analisis yang telah dilakukan, diperoleh nilai konstanta pada variabel kecerdasan emosional yang dapat digunakan untuk memprediksi varians yang terjadi pada variabel agresivitas. Persamaan regresi yang digunakan adalah $\mathrm{Y}=55.802+(-0.337) \mathrm{X}$. Koefisien regresi bernilai negatif yaitu sekitar 0.337 , yang berarti setiap penambahan 1 poin kecerdasan emosional, maka akan menurunkan nilai agresivitas sebesar 0.337 poin.

Persamaan garis regresi yang diperoleh kemudian diuji pada aspek validitas dalam memprediksi variabel agresivitas. Dasar pengambilan keputusan menggunakan nilai signifikansi probabilitas yaitu apabila nilai $\mathrm{p}<0.05$ maka koefisien regresi adalah signifikan atau valid. Berdasarkan nilai tabel 9 yang menunjukkan perbedaan nilai mean atau $\mathrm{t}$ hitung sebesar 3.962 dengan probabilitas 0.000 maka dapat dikatakan bahwa koefisien regresi yang diperoleh memang signifikan atau valid. Hal ini berarti bahwa antara variabel kecerdasan emosional dan variabel agresivitas memiliki hubungan fungsional atau saling memengaruhi.

Pengujian validitas juga dilakukan pada konstanta yang diperoleh. Hasil analisis regresi menunjukkan nilai konstanta sebesar 55.802. Nilai $t$ hitung sebasar 13.622 dengan signifikansi probabilitas 0.000 . Apabila nilai $\mathrm{p}<0.05$ maka regresi dinyatakan valid atau signifikan. Berdasarkan nilai probabilitas yang diperoleh sebesar $0.000<0.05$ maka dapat dikatakan bahwa konstanta regresi yang diperoleh adalah valid atau signifikan.

Berdasarkan hasil uji validitas konstanta dan persamaan garis regresi, maka dapat disimpulkan bahwa persamaan regresi dalam penelitian ini adalah signifikan dan dapat digunakan untuk memprediksi perubahan nilai yang terjadi pada variabel agresivitas apabila nilai variabel kecerdasan emosional dimanipulasi, serta diantara kedua variabel memiliki hubungan fungsional atau saling mempengaruhi.

\section{Analisis Tambahan}

Peneliti melakukan analisis tambahan pada data tambahan. Analisis yang digunakan adalah independent sample t-test. Peneliti ingin mengetahui apakah terdapat perbedaan kecerdasan emosional serta agresivitas apabila dilihat dari jenis kelamin.

Perbedaan Kecerdasan Emosional Berdasarkan Jenis Kelamin. Peneliti melakukan uji beda terhadap kecerdasan emosional berdasarkan jenis kelamin dengan menggunakan independent sample t-test. Sebelum melakukan uji independent sample $t$ test perlu melihat sebaran data normal atau tidak. Hasil uji normalitas dan hasil uji independent sample t-test dapat dilihat pada tabel 10 dan 11 (terlampir). Hasil uji homogenitas dengan Levene's test for equality of variance pada tabel 10 terlihat nilai $\mathrm{F}$ sebesar 0.813 dengan nilai probabilitas sebesar 0.368 ( $p>0.05)$ maka dapat dikatakan sebaran data bersifat homogen. Hasil uji independent sample t-test. Pada tabel 11 menunjukkan nilai signifikansi sebesar 0.057 ( $\mathrm{p}>0.05)$ maka dapat dikatakan bahwa mean skor kecerdasan emosional tidak berbeda secara signifikan berdasarkan jenis kelamin.

Perbedaan Agresivitas Berdasarkan Jenis Kelamin.

Peneliti melakukan uji beda terhadap agresivitas berdasarkan jenis kelamin dengan menggunakan independent sample t-test. Sebelum melakukan uji independent sample t-test perlu melihat sebaran data normal atau tidak. Hasil uji normalitas dan hasil uji independent sample t-test dapat dilihat pada tabel 12 dan 13 (terlampir). Hasil uji homogenitas dengan Levene's test for equality of variance pada tabel 12 terlihat nilai $\mathrm{F}$ sebesar 0.187 dengan nilai probabilitas sebesar $0.666(p>0.05)$ maka dapat dikatakan sebaran data bersifat homogen. Hasil uji independent sample t-test. Pada tabel 13 menunjukkan nilai signifikansi sebesar $0.568(\mathrm{p}>0.05)$ maka dapat dikatakan bahwa mean skor agresivitas tidak berbeda secara signifikan berdasarkan jenis kelamin.

\section{PEMBAHASAN DAN KESIMPULAN}

Berdasarkan hasil penelitian yang telah dilakukan dan dianalisis dengan menggunakan teknik analisis regresi sederhana, dapat dinyatakan bahwa hipotesis alternatif diterima, sehingga dapat dikatakan bahwa terdapat hubungan negatif yang signifikan antara kecerdasan emosional dengan agresivitas pada remaja madya di SMA Dwijendra Denpasar $(\mathrm{p}=0.000 ; \mathrm{r}=-0.227)$. Nilai koefisien determinasi ( $\mathrm{R}$ square) adalah sebesar 0.051 yang berarti variabel kecerdasan emosional mampu menjelaskan variabel agresivitas sebesar $5,1 \%$, sedangkan sebanyak 94,9\% dijelaskan oleh variabel lain yang tidak diteliti dalam penelitian ini. Meskipun varians yang dapat dijelaskan nilainya kecil namun hubungan antara agresivitas dan kecerdasan emosional dapat diyakini sebagai hubungan yang fungsional.

Nilai koefisien korelasi yang menunjukkan nilai negatif mengartikan bahwa terdapat hubungan yang tidak searah atau berlawanan arah antara variabel kecerdasan emosional dengan agresivitas. Apabila terjadi kenaikan pada nilai kecerdasan emosional, maka akan terjadi penurunan pada nilai agresivitas dan begitu pula sebaliknya.

Pada hasil pengujian model regresi diperoleh hasil bahwa model regresi adalah signifikan $(\mathrm{p}=0.000)$, sehingga dapat digunakan untuk tujuan prediksi variabel tergantung melalui variabel bebas atau dengan kata lain, variabel agresivitas dapat diprediksi oleh kecerdasan emosional. Hal ini ditunjukkan dengan hasil analisis yang menyatakan bahwa penambahan 1 poin nilai kecerdasan emosional, maka akan menurunkan nilai agresivitas sebesar 0.337 poin. Pengujian pada persamaan garis regresi diperoleh hasil bahwa koefisien regresi adalah signifikan $(p=0.000)$ dan konstanta regresi juga signifikan $(\mathrm{p}=0.000)$. Oleh karena itu, antara variabel kecerdasan 
emosional dan agresivitas memiliki fungsional atau saling memengaruhi.

Berdasarkan hasil hipotesis, diperoleh bahwa hipotesis alternatif yang diajukan dalam penelitian ini diterima atau dengan kata lain, terdapat hubungan negatif yang signifikan antara kecerdasan emosional dengan agresivitas pada remaja madya di SMA Dwijendra Denpasar. Semakin tinggi kecerdasan emosional remaja maka kecenderungan agresivitasnya semakin rendah, begitu juga sebaliknya, semakin rendah kecerdasan emosional remaja maka kecenderungan agresivitasnya semakin tinggi. Hasil penelitian ini juga sesuai dengan penelitian Setiawati (2015) yang menyatakan bahwa terdapat hubungan negatif yang signifikan antara kecerdasan emosional dengan perilaku agresi remaja. Selain itu, Arini (2016) menyatakan hal yang sama dari hasil penelitiannya bahwa terdapat korelasi negatif antara kecerdasan emosional dengan perilaku agresif siswa kelas VIII SMP Negeri 1 Semen Kediri.

Hasil kategorisasi data kecerdasan emosional dapat dilihat bahwa tidak terdapat subjek yang masuk kedalam katagori sangat rendah. Subjek yang termasuk dalam kategori rendah berjumlah 9 orang atau 3,1\%, sedangkan subjek yang masuk ke dalam kategori sedang sebanyak 92 orang atau $31,5 \%$, subjek yang masuk ke kategori tinggi sebanyak 180 orang atau $61,6 \%$, subjek yang masuk kedalam kategori sangat tinggi berjumlah 11 orang atau $3,8 \%$, dan dapat disimpulkan bahwa remaja di SMA Dwijendra Denpasar memiliki tingkat kecerdasan emosional yang tinggi.

Menurut Goleman (2001), menjelaskan bahwa kecerdasan emosional adalah kemampuan untuk mengenali perasaan diri sendiri dan perasaan orang lain, kemampuan memotivasi diri sendiri dan kemampuan mengelola emosi dengan baik pada diri sendiri dan dalam hubungan dengan orang lain. Apabila individu pandai menyesuaikan diri dengan suasana hati individu lain, maka akan memiliki tingkat emosionalitas yang baik sehingga lebih mudah menyesuaikan diri dalam pergaulan sosial. Memiliki kecerdasan emosional yang cukup baik, menjadikan individu mampu menempatkan emosi secara tepat, memilah kepuasan dan mengatur suasana hati. Selain itu, Palmer (dalam Setiawati, 2015) menyatakan bahwa kecerdasan emosional yang tinggi adalah salah satu faktor penentu kepuasan hidup yang pada akhirnya akan menekan tingkat perilaku agresi. Berdasarkan hasil kategorisasi data kecerdasan emosional, remaja madya SMA Dwijendra Denpasar memiliki tingkat kecerdasan emosional yang tinggi, hal ini menjelaskan bahwa siswa SMA Dwijendra Denpasar sudah mampu untuk menempatkan emosi secara tepat, memilah kepuasan dan mengatur suasana hati.

Hasil kategorisasi data agresivitas dapat dilihat bahwa subjek yang masuk kedalam kategori sangat rendah berjumlah 14 orang atau 4,8\%. Subjek yang termasuk dalam kategori rendah berjumlah 84 orang atau $28,8 \%$, sedangkan subjek yang masuk kedalam kategori sedang sebanyak 134 orang atau $45,9 \%$, subjek yang masuk kategori tinggi sebanyak 52 orang atau $17,8 \%$, subjek yang masuk kedalam kategori sangat tinggi berjumlah 8 orang atau 2,7\%, dan dapat disimpulkan bahwa remaja di SMA Dwijendra Denpasar memiliki tingkat agresivitas yang sedang.
Menurut Martono (dalam Dwi Bakhiar \& Andik, 2012) faktor penyebab timbulnya agresi antara lain faktor pribadi, remaja dituntut untuk menyesuaikan diri dengan lingkungannya. Di sisi lain, remaja harus mengembangkan identitas diri secara positif. Terjadinya krisis identitas pada remaja dapat menimbulkan ketegangan (stres) dan kecemasan pada remaja. Faktor keluarga juga dapat menyebabkan timbulnya agresi, karena keluarga merupakan lingkungan pendidikan yang utama dan pertama bagi anak. Jika suasana keluarga kurang mendukung, dapat menyebabkan terjadinya gangguan perkembangan kejiwaan anak. Selain faktor pribadi dan keluarga, lingkungan kelompok sebaya juga dapat menyebabkan perilaku agresi, karena jika kondisi di rumah kurang menunjang, anak akan mencari perhatian dan identitas diri diluar, sehingga pengaruh teman sebaya ini sangat besar.

Martono (dalam Dwi Bakhiar \& Andik, 2012) juga mengatakan bahwa lingkungan sekolah juga merupakan salah satu faktor yang menyebabkan munculnya perilaku agresi. Kondisi sekolah yang tidak kondusif, keadaan guru dan sistem pengajaran yang tidak menarik menyebabkan anak cepat bosan. Untuk menyalurkan rasa tidak puasnya, remaja meninggalkan sekolah atau membolos dan bergabung dengan kelompok anak-anak yang tidak sekolah, yang kegiatannya tanpa tujuan yang jelas. Dari hasil penelitian ini, rata-rata siswa SMA Dwijendra Denpasar memiliki agresivitas yang sedang. Buss dan Perry (dalam Bryant \& Smith 2001) mengatakan semakin tinggi agresivitas yang dimiliki individu, maka individu tersebut akan memiliki intensitas dan frekuensi berperilaku agresif yang tinggi, seperti lebih sering menghujat, berkelahi, bermusuhan dan juga marah, sedangkan individu yang memiliki tingkat agresivitas sedang akan lebih jarang untuk berperilaku agresif. Sehingga dapat dikatakan bahwa sebagian besar remaja madya di SMA Dwijendra Denpasar adalah remaja yang mampu mengendalikan dorongan untuk berperilaku agresif.

Hasil analisis data tambahan menunjukkan bahwa tidak terdapat perbedaan yang signifikan pada kecerdasan emosional maupun agresivitas berdasarkan jenis kelamin pada remaja madya di SMA Dwijendra Denpasar. Hal ini menunjukkan bahwa jenis kelamin tidak memiliki hubungan yang signifikan dengan tinggi rendahnya nilai kecerdasan emosional maupun agresivitas yang dimiliki individu. Tinggi rendahnya kecerdasan emosional dapat diperoleh dari pengalaman dalam kehidupan dan lingkungan tempat individu berada. Hal ini sejalan dengan pendapat Suharsono (dalam Musyarrafah, 2016) yang menyebutkan bahwa kecerdasan emosional sangat tergantung pada proses pendidikan yang diberikan oleh orang tua maupun lingkungan sekitar. Sedangkan pada variabel agresivitas menyebutkan bahwa setiap individu baik perempuan maupun laki-laki kemungkinan besar akan terlibat dalam perilaku agresif. Namun, keterlibatan laki-laki dalam perilaku agresif lebih cenderung pada agresi relasional teman sebaya baik proaktif maupun reaktif terhadap situasi tertentu sedangkan keterlibatan perempuan dalam perilaku agresif cenderung melakukan agresi relasional romantis (Saputra, Hanifah \& Widagdo, 2017).

Kelemahan dan hambatan dalam penelitian ini adalah terkait dengan proses birokrasi perizinan untuk melakukan penelitian. 
Peneliti dalam mencari izin penelitian membutuhkan waktu yang cukup panjang, karena peneliti diminta mencari surat di beberapa dinas yang berbeda sebelum mendapatkan izin untuk melakukan penelitian pada tempat yang telah ditentukan. Selain itu, dalam proses pengambilan data penelitian, kehadiran guru pembimbing cukup memberikan pengaruh terhadap kenyamanan siswa dalam mengisi kuesioner.

Saran bagi remaja yaitu remaja agar mampu mengendalikan emosi dalam situasi apapun dan memahami apa penyebab dari munculnya emosi serta remaja agar mampu belajar memahami dirinya sendiri dan orang lain. Selain itu, remaja agar berusaha untuk selalu berpikir positif dan melakukan kegiatan-kegiatan yang positif baik di sekolah maupun diluar sekolah. Bagi orang tua diharapkan agar mampu menciptakan lingkungan keluarga yang positif dengan memberikan kebebasan berpendapat pada masing-masing anggota keluarga serta orangtua agar mampu memberikan contoh secara langsung kepada anak bagaimana cara mengelola emosi dengan baik. Contoh: tidak emosional ketika berhadapan dengan anak dan selalu tenang dalam menghadapi setiap masalah. Bagi pihak sekolah diharapkan sekolah agar mampu menciptakan lingkungan yang positif untuk para siswa dengan cara melakukan inovasi-inovasi dalam sistem pembelajaran untuk membuat siswa merasa lebih nyaman berada di sekolah seperti memasukan kesenian pertunjukan teater pada pelajaran seni budaya yang bertujuan untuk memberikan ruang berekspresi bagi siswa.

Saran bagi penelitian selanjutnya adalah peneliti lebih mengembangkan penelitiannya, tidak hanya terbatas pada satu lokasi penelitian tetapi lebih banyak lokasi untuk menemukan perbedaan diantara remaja madya dilokasi satu dengan lokasi lainnya. Penelitian selanjutnya yang tertarik untuk melakukan penelitian yang sama diharapkan menyertakan variabel lain yang mempengaruhi agresivitas remaja madya yang bertujuan untuk memperkaya penguasaan dibidang perkembangan perilaku agresivitas remaja serta peneliti yang ingin melakukan penelitian di sekolah diharapkan lebih memperhatikan faktor-faktor yang di luar kontrol yang mampu mempengaruhi hasil penelitian.

\section{DAFTAR PUSTAKA}

Agustiani, H. (2009). Psikologi perkembangan: Pendekatan ekologi Arini. (2016). Korelasi antara kecerdasan emosional dengan perilaku agresif siswa kelas VIII SMP Negeri 1 Semen Tahun Ajaran 2015/2016. Kediri: Universitas Nusantara PGRI Kediri.

Bryant, F. B., \& Smith, B. D. (2001). Refining the architecture of aggression: A measurement modelfor the Buss-Perry aggression questionnaire. Journal of Research in Personality, 35, 138-167. Loyola University Chicago.

Dewi, T. (2012). Hubungan antara kecerdasan emosional dan agresi pada remaja di Jakarta. Naskah tidak dipublikasikan, Fakultas Psikologi, Universitas Bina Nusantara, Jakarta.

Dwi, B. J., \& Matulessy, A. (2012). Kecerdasan emosional, kecerdasan spiritual dan agresivitas pada remaja. Jurnal Psikologi Indonesia, 1(2), 99-104.
Ghozali, I. (2012). Aplikasi analisis multivariate dengan program IBM SPSS 20 (6 ed). Semarang: Badan Penerbit Universitas Diponegoro

Goleman, D. (1995). Emotional intelligence. USA and Canada: Scientific American.

Goleman, D. (2001). Kecerdasan emosional. Jakarta: PT Gramedia Pustaka Utama.

Indrayana, P., \& Hendrati, F. (2013). Hubungan antara kecerdasan emosional dan konformitas kelompok teman sebaya dengan konsep diri remaja. Jurnal Psikologi Indonesia, 2(3), 199207.

Khoirunnisa, I.. \& Lilim, H. (2014). Hubungan antara peer support dengan konsep diri pada remaja putri yang delikuen di pondok remaja inabah XVII Ciamis. Fakultas Psikologi, Universitas Islam Bandung. Bandung.

Kurniawati, Y. (2010). Hubungan bermain game online terhadap perilaku agresif remaja. Naskah tidak dipublikasikan, Fakultas Psikologi, Universitas Katolik Soegijapranata, Semarang.

Kurnia, dkk. (2012). Hubungan antara konsep diri dan kecerdasan emosi dengan agresivitas pada siswa Kelas XI Man Klaten. Jurnal Ilmiah Berkala Psikologi. 8(1), 46-62.

Monks, (2009). Tahap perkembangan masa remaja. Medical Journal New Jersey Muagman, 1980. Definisi Remaja. Jakarta: Penerbit Grafindo Jakarta.

Musyarrafah, S. (2016). Perbedaan kecerdasan emosional siswa berdasarkan program kelas dan jenis kelamin di SMAN 4 Malang, SMAN 5 Malang dan SMAN 8 Malang. Fakultas Psikologi, Universitas Islam Negeri Maulana Malik Ibrahim Malang.

Nisha, A. (2015). Hubungan konformitas dan kecerdasan emosional terhadap agresivitas pada remaja madya Di SMAN 7 Denpasar. Denpasar : Program Studi Psikologi Fakultas Kedokteran Universitas Udayana.

Purnomo. (2017). Geng motor makan korban = anggota TNI tewas dibunuh. diakses : Juli 2017, dari sumber website : http://balitribune.co.id

Putra, Angga. (2016). Miris, duo remaja ini dalangi pencurian motor di Denpasar dan dijual di OLX. diakses : Agustus, 2017, dari website : http://bali.tribunnews.com

Rohmat. (2012). Pelaku penganiayaan ABG Bali anggota geng CMP. diakses : Agustus 2017, dari website : https://okezone.com

Santoso, S. (2003). Mengatasi berbagai masalah statistika dengan SPSS versi 11.5. Jakarta: PT Elex Media Komputindo.

Santrock. J. W. (2003). Adolescence: Perkembangan remaja.(6 ed.). Jakarta: Erlangga.

Satria. (2016). Kejadian hamil di luar nikah rentan dialami cewek ABG terlibat geng motor. diakses : Agustus 2017 dari website : https://tribunnews.com

Saputra, Hanifah \& Widagdo. (2017). Perbedaan tingkat perilaku agresi berdasarkan jenis kelamin pada siswa sekolah menengah kejuruan Kota Yogyakarta. Jurnal Kajian Bimbingan dan Konseling, 2(4),2017,142-147.

Setiawati. (2015). Hubungan antara kecerdasan emosional dengan perilaku agresi remaja. Fakultas Psikologi, Universitas Muhammadiyah, Surakarta.

Sugiyono. (2013). Metode penelitian kombinasi (Mixed Methods). Bandung: Alfabeta.

Sugiyono. (2014). Metode penelitian kuantitatif kualitatif dan R\&D. Bandung: Alfabeta

Sukiswanti, Puji. (2015). Remaja tikam pelajar SMK dua kali di Bali. diakses : Agustus 2017, dari website : https://okezone.com

Surya. (2016). Polda ciduk 18 anggota geng motor. diakses : Agustus 2017, dari sumber website : http://denpostnews.com

\section{LAMPIRAN}


Tabel 1

Deskripsi Statistik Data Penelitian

\begin{tabular}{llllllll}
\hline Variabel & $\mathbf{N}$ & $\begin{array}{l}\text { Mean } \\
\text { Teoritis }\end{array}$ & $\begin{array}{l}\text { Mean } \\
\text { Empiris }\end{array}$ & $\begin{array}{l}\text { Std } \\
\text { Deviasi } \\
\text { Teoritis }\end{array}$ & $\begin{array}{l}\text { Std } \\
\text { Deviasi } \\
\text { Empiris }\end{array}$ & $\begin{array}{l}\text { Sebaran } \\
\text { Teoritis }\end{array}$ & $\begin{array}{l}\text { Sebaran } \\
\text { Empiris }\end{array}$ \\
\hline $\begin{array}{l}\text { Kecerdasan } \\
\text { Emosional }\end{array}$ & 292 & 42.5 & 47.93 & 8.5 & 4.579 & $17-68$ & $32-59$ \\
\hline Agresivitas & 292 & 40 & 39.64 & 8 & 6.811 & $16-64$ & $22-60$ \\
\hline
\end{tabular}

Tabel 2

Kategorisasi Kecerdasan Emosional

\begin{tabular}{cccc} 
Rentang nilai & Kategori & Jumlah & Persentase \\
\hline $\mathrm{X} \leq 29,75$ & Sangat rendah & 0 & 0 \\
\hline $29,75<\mathrm{X} \leq 38,25$ & Rendah & 9 & $3,1 \%$ \\
\hline $38,25<\mathrm{X} \leq 46,75$ & Sedang & 92 & $31,5 \%$ \\
\hline $46,75<\mathrm{X} \leq 55,25$ & Tinggi & 180 & $61,6 \%$ \\
\hline $55,25<\mathrm{X}$ & Sangat tinggi & 11 & $3,8 \%$ \\
\hline
\end{tabular}

Tabel 3

Kategori Agresivitas

\begin{tabular}{cccc}
\hline Rentang nilai & Kategori & Jumlah & Persentase \\
\hline $\mathrm{X} \leq 28$ & Sangat rendah & 14 & $4,8 \%$ \\
\hline $28<\mathrm{X} \leq 36$ & Rendah & 84 & $28,8 \%$ \\
\hline $36<\mathrm{X} \leq 44$ & Sedang & 134 & $45,9 \%$ \\
\hline $44<\mathrm{X}<52$ & Tinggi & 52 & $17,8 \%$ \\
\hline $52<\mathrm{X}$ & Sangat tinggi & 8 & $2,7 \%$ \\
\hline
\end{tabular}

Tabel 4

Hasil Uji Normalitas

\begin{tabular}{ccc}
\hline Variabel & Kolmogorof-smirnov & $\begin{array}{c}\text { Asymp. Sig. (2-tailed) } \\
(\mathbf{P})\end{array}$ \\
\hline Kecerdasan emosional & 1.251 & 0.087 \\
\hline Agresivitas & 0.835 & 0.488 \\
\hline
\end{tabular}


Hasil Uji Linieritas

\begin{tabular}{ccccc}
\hline & & & F & Signifikasi \\
\hline Agresivitas*Kecerdasan & Between & Combined & 2.296 & 0.001 \\
Emosional & Groups & & & \\
& & Linearity & 16.676 & 0.000 \\
& & Deviation from linearity & 1.720 & 0.020 \\
\hline
\end{tabular}

Tabel 6

Uji Korelasi Pearson Product Moment pada Regresi Sederhana

\begin{tabular}{lllll} 
Pearson correlation & $\begin{array}{l}\text { Kecerdasan } \\
\text { emosional }\end{array}$ & Agresivitas & Sig-(2-tailed) & N \\
\hline Kecerdasan Emosional & 1 & -0.227 & 0.000 & 292 \\
\hline Agresivitas & -0.227 & 1 & 0.000 & 292 \\
\hline
\end{tabular}

Tabel 7

Hasil Uji Koefisien Determinasi

\begin{tabular}{cccc}
\hline $\boldsymbol{R}$ & $\boldsymbol{R}$ Square & Adjusted $\boldsymbol{R}$ Square & $\begin{array}{c}\text { Std Error of the } \\
\text { estimate }\end{array}$ \\
\hline 0.227 & 0.051 & 0.048 & 6.645 \\
\hline
\end{tabular}

Tabel 8

Hasil Analisis Model Regresi Linear Sederhana

\begin{tabular}{cccccc}
\hline & $\begin{array}{c}\text { Sum of } \\
\text { Squares }\end{array}$ & Df & $\begin{array}{l}\text { Mean } \\
\text { Square }\end{array}$ & F & Sig- \\
\hline Regression & 693.290 & 1 & 693.290 & 15.700 & 0.000 \\
\hline Residual & 12805.669 & 290 & 44.157 & & \\
\hline Total & 13498.959 & 291 & & & \\
\hline
\end{tabular}

Tabel 9

Hasil Uji Persamaan Garis Regresi

\begin{tabular}{|c|c|c|c|c|c|}
\hline \multirow[b]{2}{*}{ Model } & \multicolumn{2}{|c|}{ Unstandarized Coefficients } & \multirow{2}{*}{$\begin{array}{c}\text { Standarized } \\
\text { Coefficient } \\
\text { Beta }\end{array}$} & \multirow[b]{2}{*}{$T$} & \multirow[b]{2}{*}{ Sig. } \\
\hline & $B$ & Std. Error & & & \\
\hline Constant & 55.802 & 4.096 & & 13.622 & 0.000 \\
\hline Kecerdasan Emosional & -0.337 & 0.085 & -0.227 & -3.962 & 0.000 \\
\hline
\end{tabular}


Hasil Uji Homogenitas Varians Populasi Berdasarkan Jenis Kelamin

\begin{tabular}{lll}
\hline Levene Statistic & F & Sig. \\
\hline & 0.813 & 0.368 \\
\hline
\end{tabular}

Tabel 11

Hasil Uji Perbedaan Kecerdasan Emosional Berdasarkan Jenis Kelamin

\begin{tabular}{ccccc}
\hline & & F & Sig. & Sig. (2-tailed) \\
\hline Total & $\begin{array}{c}\text { Equal Variances } \\
\text { Assumed }\end{array}$ & 0.813 & 0.368 & 0.057 \\
Kecerdasan Emosional & & & \\
\hline
\end{tabular}

Tabel 12

Hasil Uji Homogenitas Varians Populasi Berdasarkan Jenis Kelamin

\begin{tabular}{lll} 
Levene Statistic & F & Sig. \\
\hline & 0.187 & 0.666 \\
\hline
\end{tabular}

Tabel 13

Hasil Uji Perbedaan Agresivitas Berdasarkan Jenis Kelamin

\begin{tabular}{ccccc}
\hline & & F & Sig. & Sig. (2-tailed) \\
\hline Total & $\begin{array}{c}\text { Equal Variances } \\
\text { Assumed }\end{array}$ & 0.187 & 0.666 & 0.568 \\
Kecerdasan Emosional & & & \\
\hline
\end{tabular}

